\title{
Kunstens medier
}

Hvad kendetegner et medie? Da litteraten Marie-Laure Ryan blev bestilt til at skrive om medier og narrativitet i Routledge Encyclopedia of Narrative, kom hun i tvivl. Det kom der et essay ud af, hvor hun bl.a. skriver: "Spørg en sociolog eller kulturkritiker om at definere begrebet medie, og han eller hun vil svare:TV, radio, film, internettet. En kunstkritiker vil opliste: musik, maleri, skulptur, litteratur, drama, opera, fotografi, arkitektur. En kunstners liste ville begynde med ler, bronze, olie, vandfarver, stof, og listen kunne afsluttes med eksotiske genstande brugt i “mixed-media”, såsom græs, fjer og ølkapsler. En informationsteoretiker eller historiker ville tænke på lydbølger, papyrusruller, kodex og silikonechips".

Der er med andre ord ikke enighed om begrebet medie. At det forholder sig sådan, skyldes bl.a., at medier ikke er medier, før vi siger, at de er det. Så længe de genstande, vi sammensætter, organiserer og bearbejder, ikke gives et samlet udtryk med mening i, forbliver de blot dødt materiale. En definition af medier, som går på tværs af fagskel, kunne således lyde: Medier er intentioner og budskaber medieret gennem forskellige materialer. Definitionen er ikke specielt gangbar, hvilket sikkert også var pointen hos medieteoretikeren Marshall McLuhan, der med sin artikel "The Media is the Message" komponerede en tautologi, som efterhånden har opnået kultisk status: Mediet er budskabet.

Men hvad betyder det så? Det vil vi med Passage 48, Kunstens medier, forsøge at give en række bud på.

I artiklen "Teksten og bogsiden" beskriver Max Ipsen med udgangspunkt i den danske 6o'er-avantgarde, hvordan bogstavet og siden i en række bog-eksperimenter kommer til at indgå i nye forbindelser, der sætter bogen som medie til fornyet diskussion. I artiklen "Avantgarde som software", der hermed for første gang er oversat til dansk, viser den russisk-amerikanske kunstner og medieteoretiker Lev Manovich, hvordan det moderne computerinterface har rødder i I920'ernes avantgarde. IT-revolutionen er ifølge Manovich ikke udtryk for en nytænkning af formprincipper, men vedrører nye muligheder for tilgang til og manipulation af allerede eksisterende avantgarde-teknikker. Lars Qvortrup fortsætter temaet om avantgarden i medieæstetisk forstand. Med computerkunsten skabes der en interferens mellem værk og beskuer, som udfordrer forholdet mellem kunst og ikke-kunst. I "Apocalypse now” skriver Jacob Wamberg om telenærvær, cyborgs, medier og kunst.

Passage $48-2003$ 
Ifølge Wamberg medfører de nye digitale teknologier, at kunsten træder ind $\mathrm{i}$ virkeligheden ved ikke blot at simulere, men også udvise funktionelle egenskaber, som normalt ikke forbindes med æstetiske virkemidler. Christian Ulrik Andersen beskæftiger sig ligeledes med forholdet mellem funktion og æstetik i sin artikel "Fra Windows til sanserum". Her er vægten imidlertid lagt på den æstetiske dimension af digitale rum. Eksempelvis kan computerspillet ikke alene forklares som en udvidelse af det reelle rum. Spillet leger med det digitale rum, der overskrider brugervenlighedens behov for kontrol. I "Efter medierne” sætter Søren Andreasen og Lars Bang Larsen spørgsmålstegn ved den lukkede medieopfattelse. En moderne medieopfattelse må bygge på 'post-medier', hvor netværk, installationer, materialer og aktivitet tænkes ind i en større sammenhæng. I nummerets sidste artikel, "Bogen som medie", giver Niels Brügger et rids af bogens historiske transformationer. Litteraturens medie, bogen, er ikke blot en historisk konstant, der som en transparent ramme giver liv til litteraturen. Snarere viser bogens historiske udvikling og kunstneriske forsøg med bogen som medie, at litteratur og medie ikke er adskilte fænomener.

God læselyst!

\section{Redaktionen}

